T. 2, № 1, 2020

UDK 681.5.01

Y. Marushchak,

Lviv Polytechnic National University, Department of Electromechatronics and Computerized Electromechanical Systems, yaroslav.y.marushchak@lpnu.ua,

V. Moroz

Lviv Polytechnic National University, Department of Electromechatronics and Computerized Electromechanical Systems, volodymyr.i.moroz@lpnu.ua

V. Tsyapa

Lviv Polytechnic National University, Department of Electromechatronics and Computerized Electromechanical Systems, volodymyr.b.tsiapa@1pnu.ua

I. Holovach

Lviv Polytechnic National University, Department of Electromechatronics and Computerized Electromechanical Systems, ihor.r.holovach@lpnu.ua

I. Chupylo

Lviv Polytechnic National University, Department of Electromechatronics and Computerized Electromechanical Systems, iqorchupylo@ukr.net

\title{
INFLUENCE ANALYSIS OF UNSTABLE ZEROES AND POLES ON THE STABILITY OF THE FEEDBACK SYSTEMS
}

https://doi.org/10.23939/sepes2020.01.052

\section{(C) Marushchak Y., Moroz V., Tsyapa V., Holovac I., Chupylo I., 2020}

According to the theory of automatic control, there should be no behavior's difference between an object given by a set of transfer functions, which are respectively interconnected, and a real object, corresponding to such a theoretical structure with given transfer functions. Accordingly, a generalized analysis of the Otto Smith hypothesis regarding the stability indices in automatic control systems with unstable zeros and poles of second-order transfer functions is carried out. Due to the fact that the behavior of most technical objects can be described by a second-order transfer function, the main accent is placed on the second-order transfer function with a denominator with unstable zeros and poles. In the article, both the apparatus of transfer functions and the structural models of the appropriate level were used for the description, which made it possible to make their description evident. A generalized description of a second order automatic control system with negative feedback is made. For 
such a system, theoretical stability criteria have been formed with respect to its parameters on the basis of necessary and sufficient conditions of stability.

On the basis of the common description of the second-order transfer function, the study of automatic control systems with different variants of placement on the complex plane of unstable zeros and poles of the open system's transfer function was performed. The presentation of the material is accompanied by numerous examples, for which cases of transfer functions with both real poles and a pair of complex conjugated poles are considered. The case of both open system and feedback system is considered for each example given in the article. Both cases are illustrated in each example by bode plots and a step response.

The researches carried out in the article are illustrated by bode plots and step responses, which for each example are obtained using mathematical applications MATLAB (with the library Control System Toolbox) and Mathcad. According to the results of our research, O. Smith's conclusions about the difference in the behavior of real physical systems with unstable zeros and poles and theoretically obtained models with similar transfer functions are confirmed.

Keywords: control systems, poles and zeros of transfer function, transfer function.

\section{Introduction}

The classical theory of automatic control does not imply a difference in behavior between an idealized mathematical model or structure and a real automatic control system. This means that, in theory, there should be no difference in behavior between an object given by a set of transfer functions, which are respectively interconnected, and a real object that corresponds to such a theoretical structure with given transfer functions. This situation is consistent with the classic case where all zeros and poles of the transfer function of an existing system lie in the left complex half-plane, that is, the whole system and each of its elements are stable.

Well-known specialist in the theory of automatic control Otto Smith once suggested that an automatic control system with the same unstable ("right") zeros and poles that are shrinking, may in fact have behavior that is different from the theoretically predicted [1]. This means that such a real system will be unstable, although theoretically, compensation for these unstable zeros and poles should occur. This hypothesis of Smith in the known literature has not been investigated due to the apparent obviousness. The mathematical foundations of the theory of automatic control have been discussed in many sources [2-6], but the question of differences in the behavior of the mathematical model and the real object is not emphasized. The analysis of the behavior of systems with zeros and poles in the right complex half-plane can be found in $[6,7]$, but the authors also do not consider the problems of physical implementation and, accordingly, ensuring stability in such systems.

\section{Problem}

Thus, the goal of the research proposed in the article is to test, including by computer simulation, the influence of unstable roots on the performance of the system. Given that mathematical applications are of great help in solving the problems of automatic control theory [8], the authors have relied, in particular, on the capabilities of Mathcad and MATLAB (with the Control System Toolbox library) [8-10].

\section{Fundamentals}

The systems without feedback are being considered, which are described by transfer functions with unstable zeros and / or unstable poles, i.e., transfer functions of the form

$$
G_{p}(s)=\frac{\left(s+s_{1 z}\right)\left(s+s_{2 z}\right) \ldots\left(s-s_{i z}\right) \ldots\left(s+s_{m z}\right)}{\left(s+s_{1 p}\right)\left(s+s_{2 p}\right) \ldots\left(s-s_{i p}\right) \ldots\left(s+s_{n p}\right)} .
$$

Such a function may have one unstable zero, or one unstable pole, or one unstable zero and one unstable pole. The concept of equivalent zero is introduced, that is, in the denominator of the transfer function of a closed system there is a term equal to zero of the numerator, which is multiplied by the coefficient of rigid feedback. This term characterizes the action, in particular, of the unstable zero, on the necessary condition of stability of a closed system, or the action of a stable zero on the necessary condition of stability of the system in the presence in the transfer function of the open system of an unstable pole. 
Considering that the behavior of many real technical systems with sufficient accuracy can be approximated by the second-order transfer function, in the first approximation we will consider its generalized transfer function:

$$
G_{z}(s)=\frac{s-z_{1}}{\left(s-p_{1}\right)\left(s-p_{2}\right)},
$$

where $z_{1}$-transfer function's zero; $p_{1}, p_{2}-$ second order transfer function's poles.

Accordingly, the structure of a feedback system with feedback value $K$ is shown in Fig. 1, and its transfer function will look like

$$
G_{z}(s)=\frac{\frac{s-z_{1}}{\left(s-p_{1}\right)\left(s-p_{2}\right)}}{1+K \cdot \frac{s-z_{1}}{\left(s-p_{1}\right)\left(s-p_{2}\right)}}=\frac{s-z_{1}}{s^{2}+\left(K-\left(p_{1}+p_{2}\right)\right) \cdot s+\left(p_{1} p_{2}-K \cdot z_{1}\right)} .
$$

Accordingly, the required stability conditions for a second-order system will look like this:

1) $p_{1} p_{2}>K \cdot z_{1}$

2) $\left(p_{1}+p_{2}\right)<K$.

Schematic diagram for a second function denominator corresponding to the transfer function shown above is shown in Fig. 2.

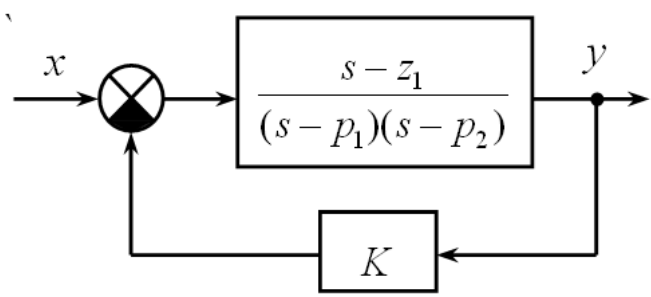

Fig. 1. A variant of the second-order structural model

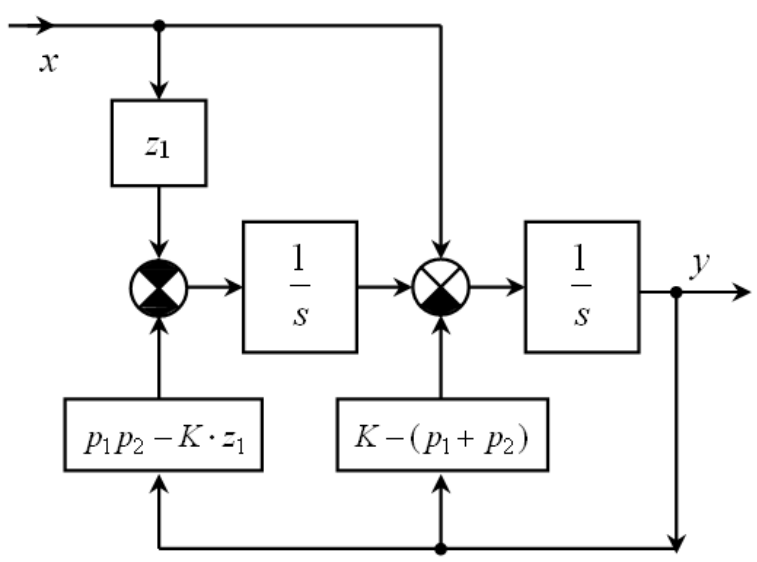

Fig. 2. Structural diagram of the second-order transfer function

Let us illustrate by simple examples the above.

\section{Example 1}

Let us have an open-loop system (its characteristics are shown in Fig. 3)

$$
G_{p}(s)=\frac{s-z_{1}}{\left(s-p_{1}\right)\left(s-p_{2}\right)}=\frac{s-3}{(s+1)(s+4)},
$$

де $z_{1}=3-$ transfer function's zero; $p_{1}=-1, p_{2}=-4-$ second order transfer function's poles.

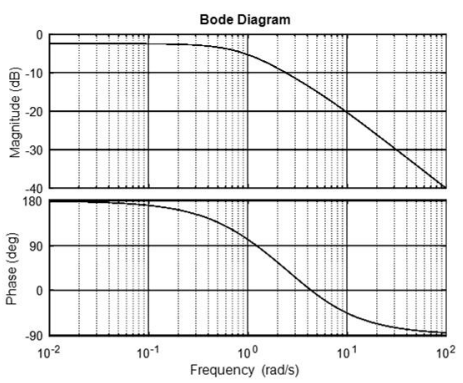

$a$

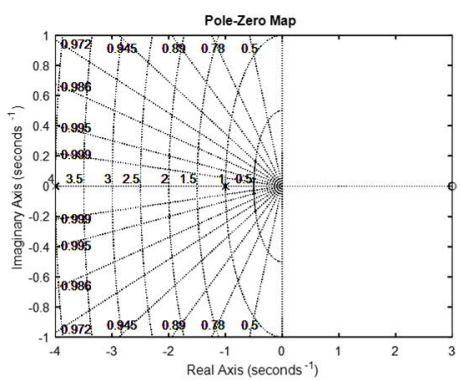

$b$

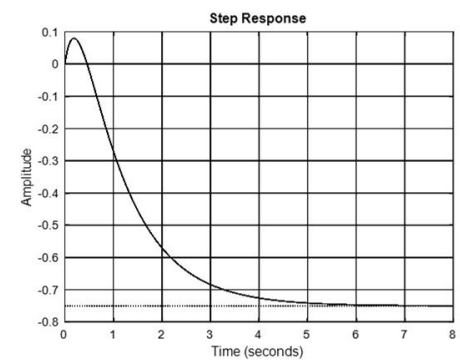

$c$

Fig. 3. Frequency response (a), zeros $(x) /$ poles $(o)(b)$ and step response $(c)$ for open transfer function 
The transfer function of such a unity feedback system will look like

$$
G(s)=\frac{\frac{s-z_{1}}{\left(s-p_{1}\right)\left(s-p_{2}\right)}}{1+\frac{s-z_{1}}{\left(s-p_{1}\right)\left(s-p_{2}\right)}}=\frac{s-3}{s^{2}+6 s+1}
$$

and will stable (see Fig. 4), because the necessary and sufficient condition is fulfilled.

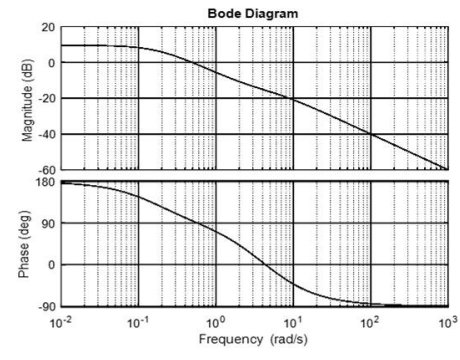

$a$

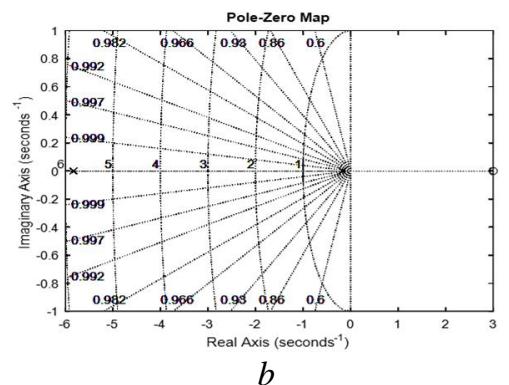

$b$

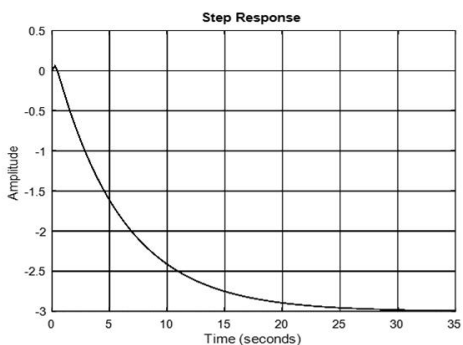

$c$

Fig. 4. Bode plots (a), zeros (x)/poles (o) (b), and transition function (c) for a closed transfer function

\section{Example 2}

Now let's change the system parameters from the previous example to get this open-loop system transfer function

$$
G_{p}(s)=\frac{s-z_{1}}{\left(s-p_{1}\right)\left(s-p_{2}\right)}=\frac{s-3}{(s+1)(s+2)},
$$

де $\quad z_{1}=3-$ transfer function's zero; $p_{1}=-1, p_{2}=-2-$ second order transfer function's poles.

Its characteristics are illustrated in Fig. 5.

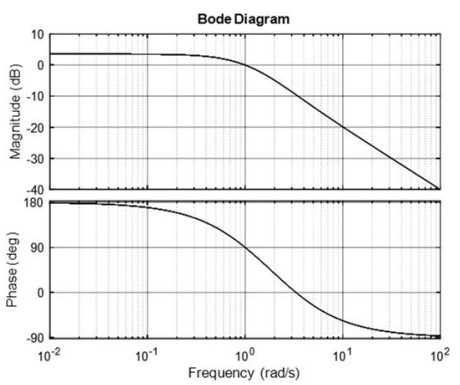

$a$

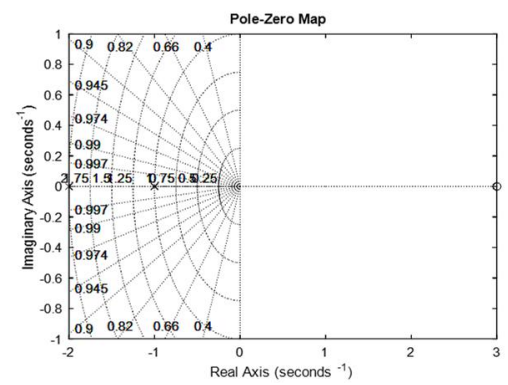

$b$

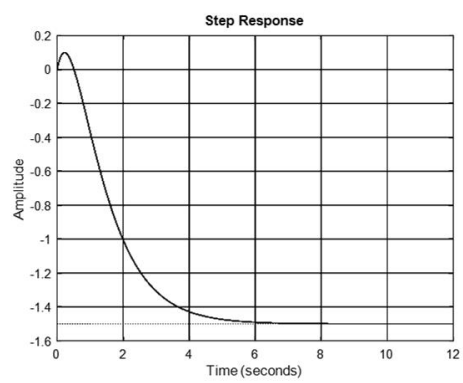

$c$

Fig. 5. Frequency response (a), zeros $(\mathrm{x}) /$ poles $(\mathrm{o})(\mathrm{b})$ and step response $(c)$ for open transfer function

Unity feedback systems will in this case be described by such a transfer function:

$$
G(s)=\frac{\frac{s-z_{1}}{\left(s-p_{1}\right)\left(s-p_{2}\right)}}{1+\frac{s-z_{1}}{\left(s-p_{1}\right)\left(s-p_{2}\right)}}=\frac{s-3}{s^{2}+4 s-1} .
$$

The resulting system will be unstable (see Fig. 6 ) because the necessary stability condition is not fulfilled.

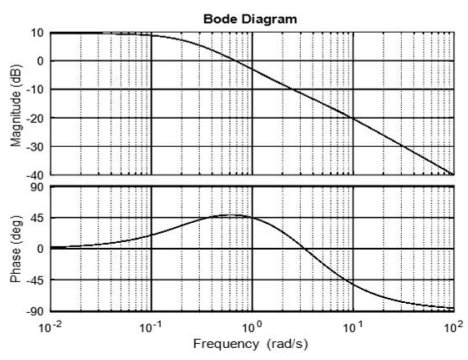

$a$

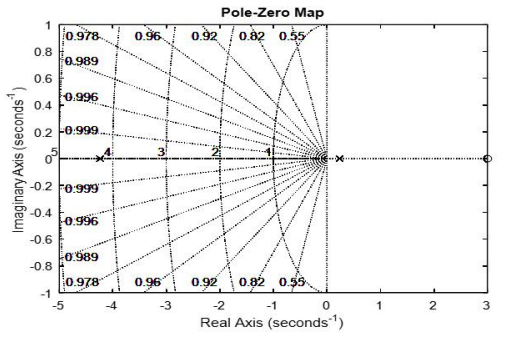

$b$

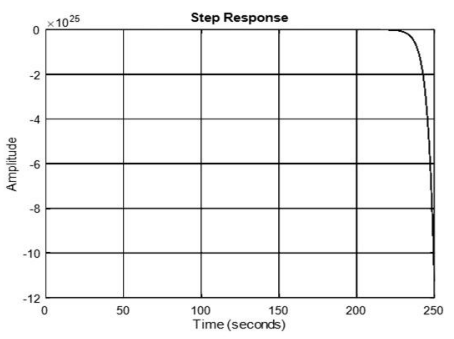

$c$

Fig. 6. Bode plots (a), zeros (x)/poles (o) (b), and transition function (c) for a closed transfer function 
Thus, the open-loop system of example 1 with unstable zero and stable poles, provided that its feedback may be stable, and may be unstable depending on the value of unstable zero.

\section{Example 3}

We show that a system with stable zero and unstable pole (see Fig. 7) can again be either stable or unstable in the case of its closure loop depending on the value of stable zero, e.g.,

$$
G_{p}(s)=\frac{s-z_{1}}{\left(s-p_{1}\right)\left(s-p_{2}\right)}=\frac{s+3}{(s-1)(s+4)},
$$

де

$z_{1}=-3-$ transfer function's zero; $p_{1}=1, p_{2}=-4-$ second order transfer function's poles.

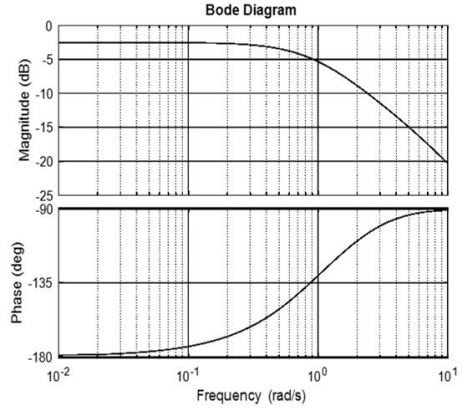

$a$

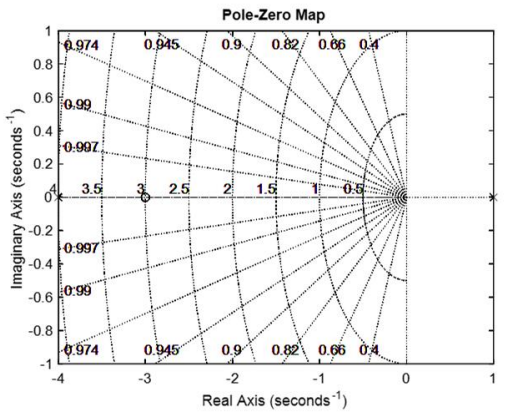

$b$

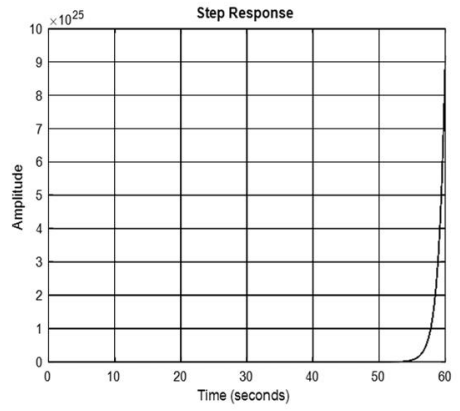

c

Fig. 7. Frequency response (a), zeros (x)/poles (o) (b) and step response (c) for open transfer function

Then a unity feedback system will have a transfer function

$$
G(s)=\frac{\frac{s-z_{1}}{\left(s-p_{1}\right)\left(s-p_{2}\right)}}{1+\frac{s-z_{1}}{\left(s-p_{1}\right)\left(s-p_{2}\right)}}=\frac{s+3}{s^{2}+4 s-1} .
$$

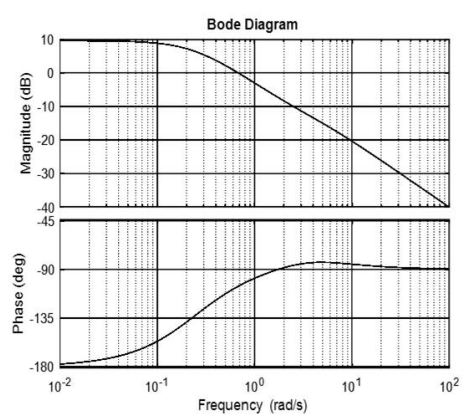

$a$

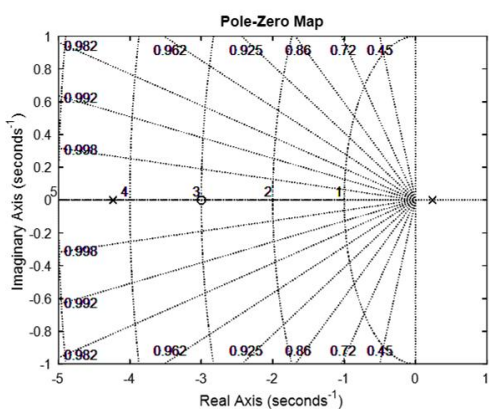

$b$

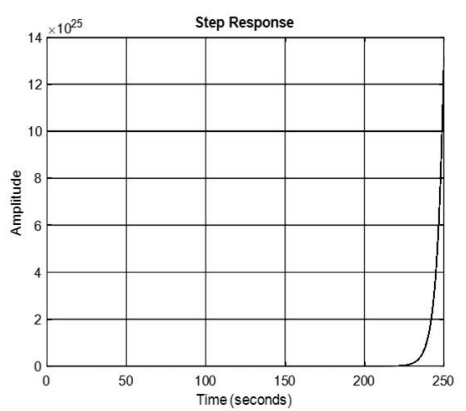

$c$

Fig. 8. Bode plots (a), zeros (x)/poles (o) (b), and transition function (c) for a closed transfer function

This unity feedback system is unstable (see Fig. 8).

\section{Example 4}

Consider the transfer function of an open-loop system with the following parameters:

$$
G_{p}(s)=\frac{s-z_{1}}{\left(s-p_{1}\right)\left(s-p_{2}\right)}=\frac{s+3}{(s+1)(s-4)},
$$

де $z_{1}=-3$ - transfer function's zero; $p_{1}=-1, p_{2}=4-$ second order transfer function's poles. 


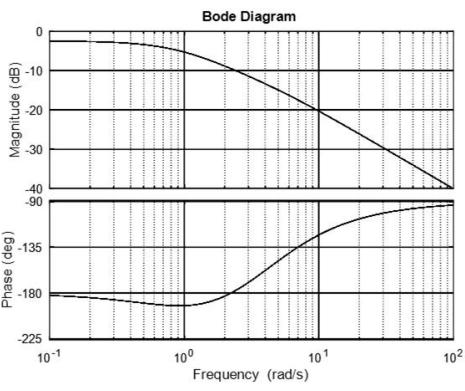

$a$

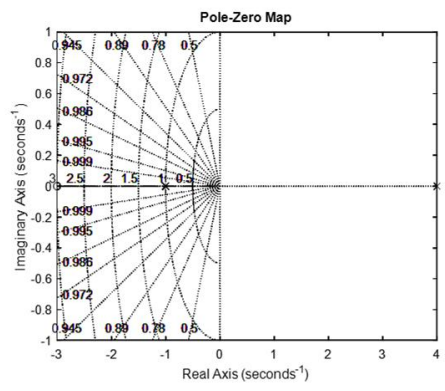

$b$

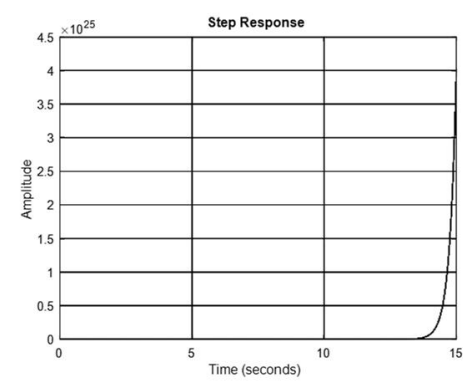

$c$

Fig. 9. Frequency response (a), zeros $(\mathrm{x}) /$ poles $(\mathrm{o})(\mathrm{b})$ and step response $(c)$ for open transfer function

Then the closed-loop system with unity feedback is also unstable due to no fulfillment of the necessary stability condition (see Fig. 10):

$$
G(s)=\frac{\frac{s-z_{1}}{\left(s-p_{1}\right)\left(s-p_{2}\right)}}{1+\frac{s-z_{1}}{\left(s-p_{1}\right)\left(s-p_{2}\right)}}=\frac{s+3}{s^{2}-2 s-1} .
$$

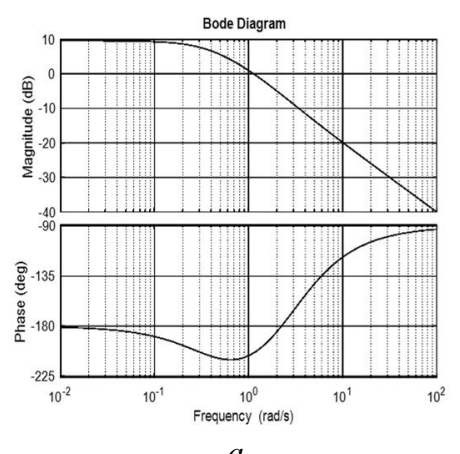

$a$

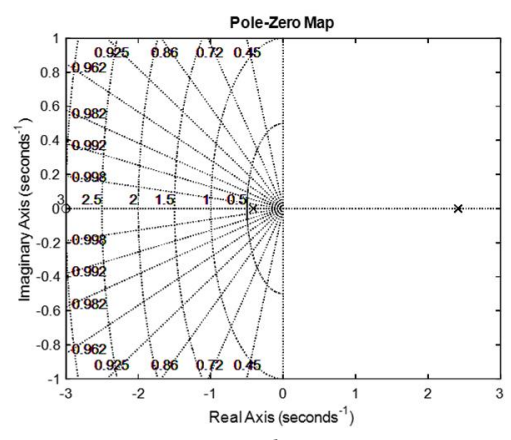

$b$

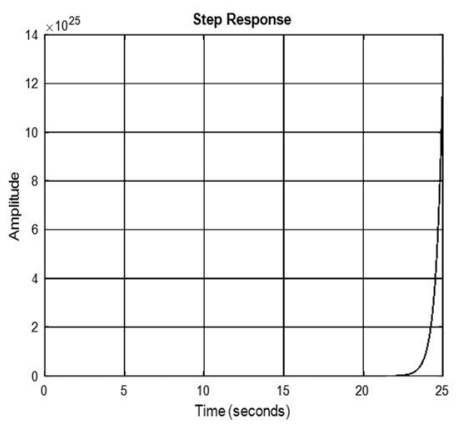

$c$

Fig. 10. Bode plots (a), zeros (x)/poles (o) (b), and transition function (c) for a closed transfer function

\section{Example 5}

In the case of stable zero $s-z_{1}=4 s+5$ provided $p_{1}=-1, p_{2}=4$ (see the characteristics of such a system in Fig. 11) we obtain the following transfer function of the open-loop system

$$
G_{p}(s)=\frac{s-z_{1}}{\left(s-p_{1}\right)\left(s-p_{2}\right)}=\frac{4 s+5}{(s+1)(s-4)} .
$$

It corresponds to the transfer function of a stable closed-loop system (see its characteristics in Fig. 12):

$$
G(s)=\frac{4 s+5}{s^{2}+s+1} .
$$

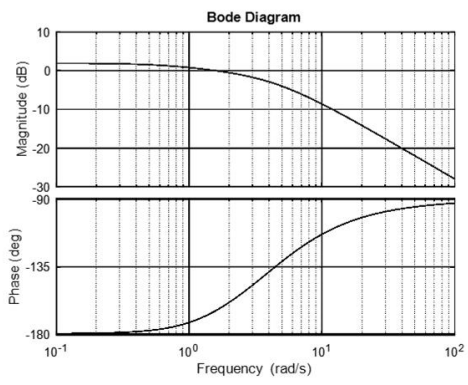

$a$

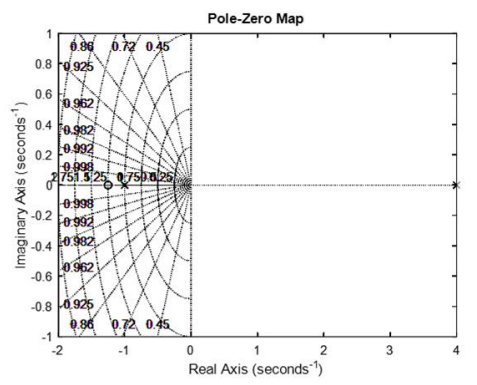

b

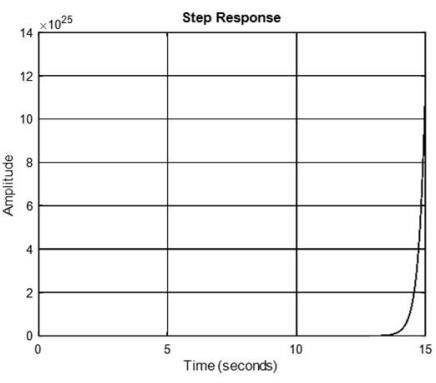

$c$

Fig. 11. Frequency response (a), zeros (x)/poles (o) (b) and step response (c) for open transfer function 


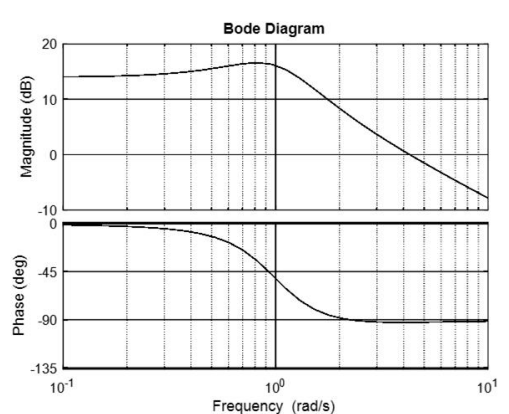

$a$

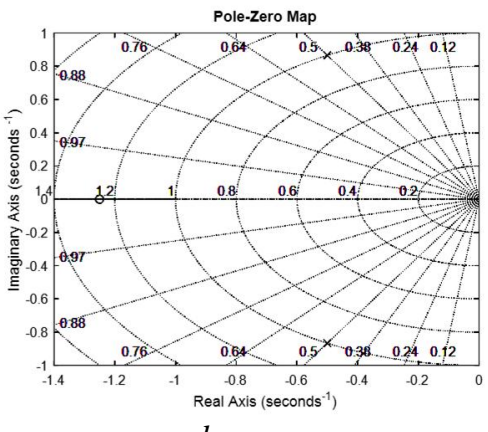

$b$

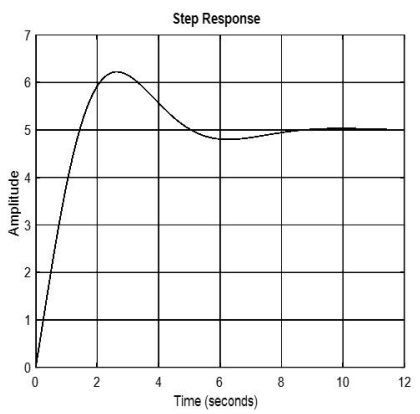

$c$

Fig. 12. Bode plots (a), zeros (x)/poles (o) (b), and step response (c) for a closed transfer function

\section{Example 6}

It is just as easy to show that an open-loop system with an unstable zero and an unstable pole will always be unstable when closed. Let

$$
G_{p}(s)=\frac{s-z_{1}}{\left(s-p_{1}\right)\left(s-p_{2}\right)}=\frac{s-3}{(s-1)(s+4)},
$$

де $z_{1}=3-$ transfer function's zero; $p_{1}=1, p_{2}=-4-$ second order transfer function's poles.

It is obvious that such a system is unstable (see its characteristics in Fig. 13).

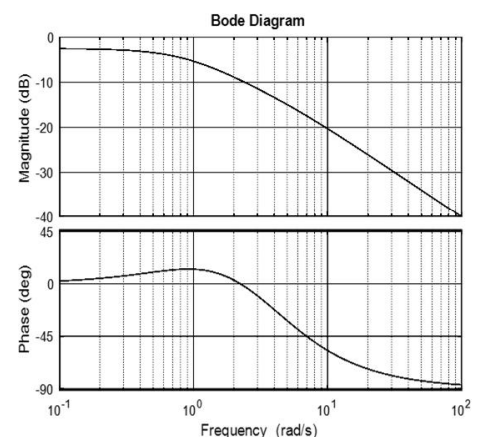

$a$

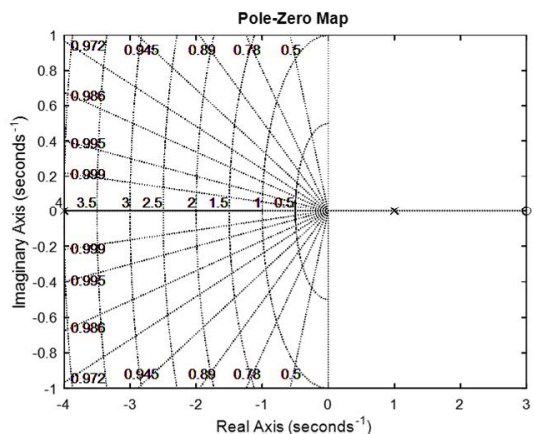

$b$

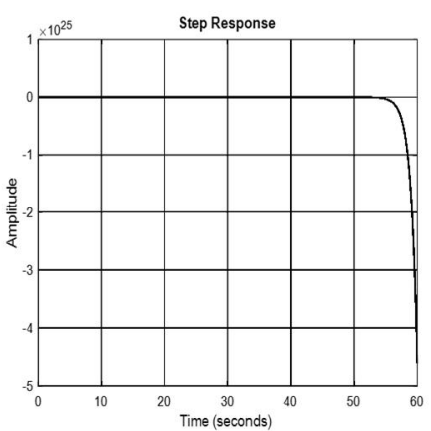

C

Fig. 13. Frequency response (a), zeros (x)/poles (o) (b) and step response (c) for open transfer function

The closed-loop transfer function will look like

$$
G(s)=\frac{\frac{s-z_{1}}{\left(s-p_{1}\right)\left(s-p_{2}\right)}}{1+\frac{s-z_{1}}{\left(s-p_{1}\right)\left(s-p_{2}\right)}}=\frac{s-3}{s^{2}+4 s-7} .
$$

The closed-loop system obtained is also unstable (see its characteristics in Fig. 14).

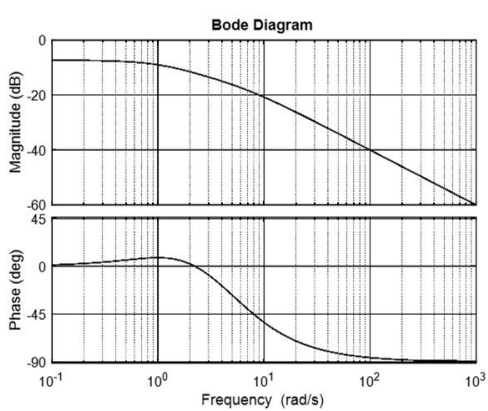

$a$

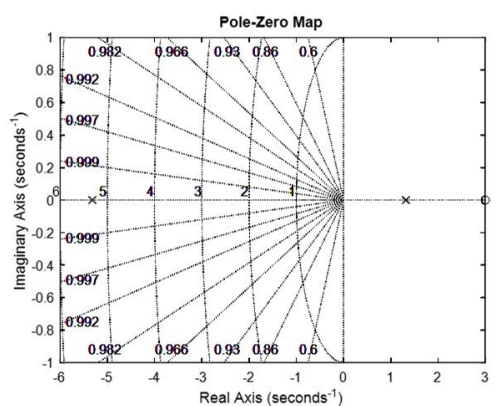

$b$

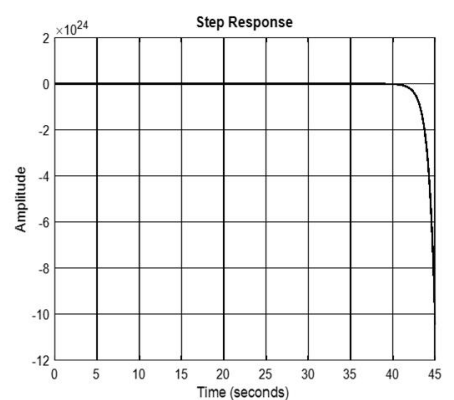

$c$

Fig. 14. Bode plots (a), zeros (x)/poles (o) (b), and step response (c) for a closed transfer function 
In the case of

$$
G_{p}(s)=\frac{s-z_{1}}{\left(s-p_{1}\right)\left(s-p_{2}\right)}=\frac{s-3}{(s+1)(s-4)},
$$

where $z_{1}=3-$ transfer function's zero; $p_{1}=-1, p_{2}=4 \quad-$ second order transfer function's poles.

The characteristics of such a system are shown in Fig. 15.

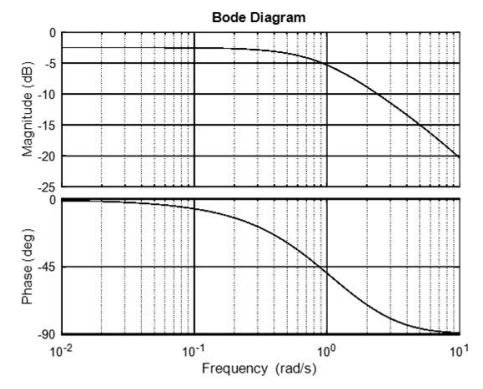

$a$

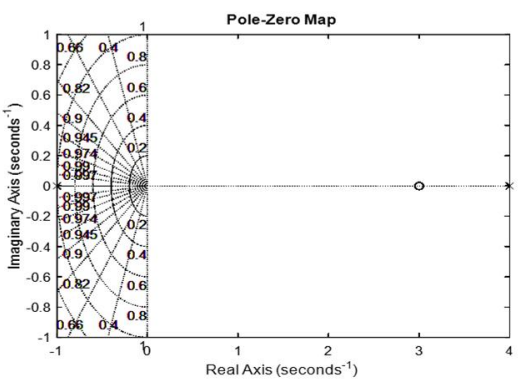

b

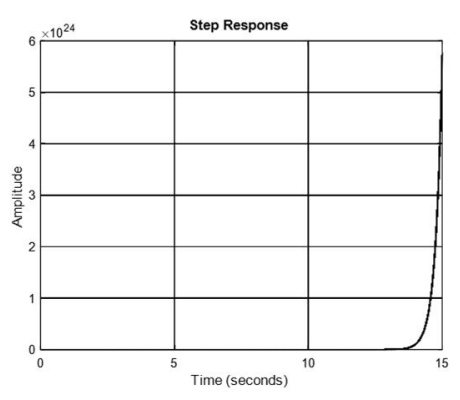

$c$

Fig. 15. Frequency response (a), zeros (x)/poles (o) (b) and step response (c) for open transfer function

The closed system is described by a transfer function and will be unstable (see its characteristics in Fig. 16):

$$
G(s)=\frac{s-3}{s^{2}-2 s-7} .
$$

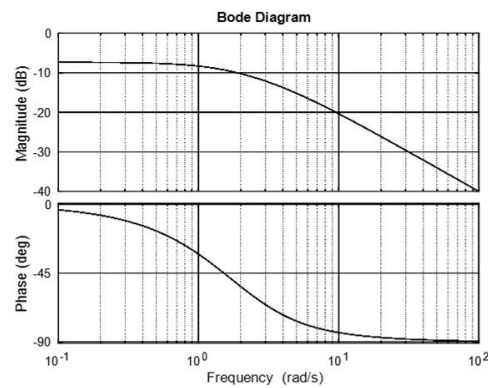

$a$

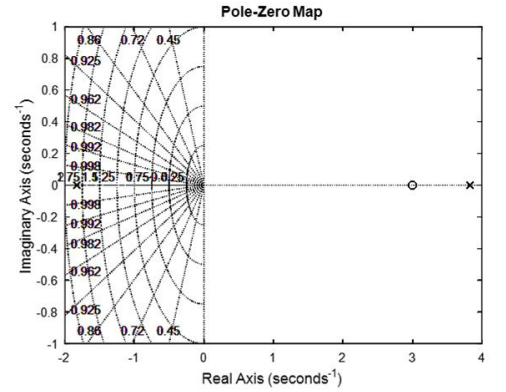

$b$

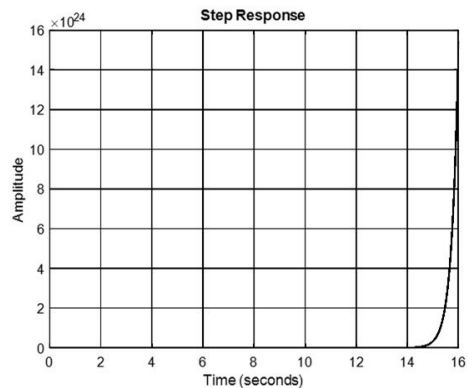

$c$

Fig. 16. Bode plots (a), zeros (x)/poles (o) (b), and step response (c) for a closed transfer function

In the next step, let us consider a more complex case - the case of complex conjugated roots. If we consider the second-order dynamic block, and this block is the most used to describe any dynamic process, then only complex-connected poles (denominator roots) can be in the transfer function. Complex-conjugate zeros cannot be based on the known Heaviside decomposition theorem for a correct fractional-rational function.

\section{Example 7}

For example, let a characteristic polynomial have the form $H(s)=2 s^{2}+3 s+4 \mathrm{v} 2 s^{2}+3 s+4=0$.

Then

$$
S_{1 p}=\frac{-3+\sqrt{9-32}}{4}=\frac{-3+j \sqrt{23}}{4}, S_{2 p}=\frac{-3-\sqrt{9-32}}{4}=\frac{-3-j \sqrt{23}}{4},
$$

and their product is $H(s)=\left(s-\frac{-3+\sqrt{9-32}}{4}\right)\left(s-\frac{-3-j \sqrt{23}}{4}\right)=2 s^{2}+3 s+4$.

In the example shown, the poles are pairwise stable. In the case where the roots of the transfer function of a dynamical system, which are a pair of stable complex-coupled poles and unstable zero, the 
required condition of stability of the closed system will be determined by the equivalent unstable zero, and this condition will coincide with the variant with real roots.

If we have a pair of unstable poles, then again the necessary condition of stability of the closed system will be determined by the value of equivalent unstable or stable zero.

\section{Example 8}

For example,

$$
G_{p}(s)=\frac{4 s-1}{2 s^{2}-3 s+4} \text { i } G(s)=\frac{4 s-1}{2 s^{2}+(4 K-3) \cdot s+(4-K)},
$$

feedback system is stable in region $3 / 4<K<4$ and is unstable for $K>4$.

Similarly, in the case of stable zero

$$
G_{p}(s)=\frac{4 s+1}{2 s^{2}-3 s+4} \text { i } G(s)=\frac{4 s+1}{2 s^{2}+(4 K-3) \cdot s+(K+4)},
$$

a closed-loop system is stable for all values of $K>3 / 4$.

The open-loop system with the same unstable zero and pole is formally stable, but in fact such a system is open-loop and closed-loop unstable. For example, consider the serial connection of an object (plant) to a transfer function

and controller

$$
W(s)=\frac{1}{s-1}
$$

$$
W_{\text {contr }}(s)=\frac{s-1}{s+1}
$$

The structural models of the blocks corresponding to the transfer functions shown above are shown in Fig. 17.
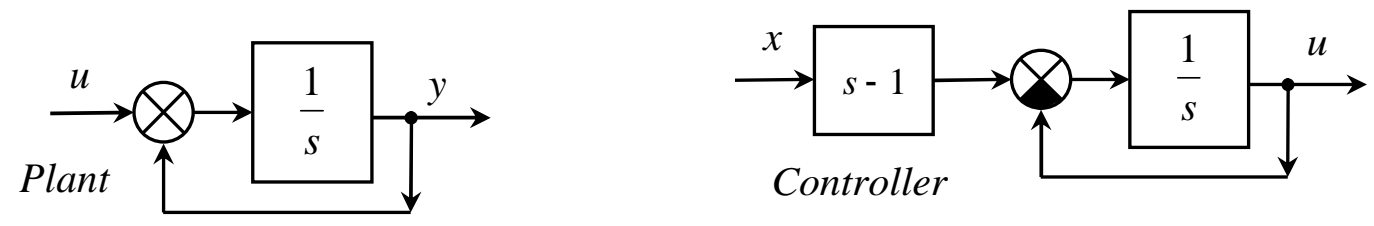

Fig. 17. Blocks' structure models

The consistent connection of these units corresponds to the structure shown in Fig. 18, where $x-$ input signal; $u$ - controlling signal, $y$ - output signal.

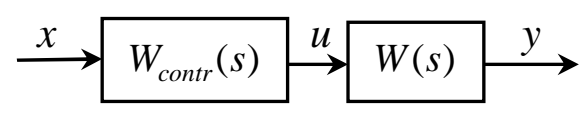

Fig. 18. Connection of blocks

The corresponding differential equations are of the form:

Where $\dot{u}+u=\dot{x}-x, \dot{y}-y=u$.

$$
\begin{aligned}
& u=\frac{s-1}{s+1} \cdot x \\
& y=\frac{1}{s-1} \cdot u,
\end{aligned}
$$

Now substitute $u$ in the first equation and get

$$
\ddot{y}-\dot{y}+\dot{y}-y=\dot{x}-x \text { або } \quad \ddot{y}-y=\dot{x}-x .
$$

Such a differential equation is unstable because its solution has the form

$$
y(t)=C_{1} e^{t}+C_{2} e^{-t},
$$

and this solution increases with increasing $t$, even under infinitesimal initial conditions $y(0)=\varepsilon$ i $\dot{y}(0)=0$.

Note that these values are included in expressions for $C_{1}=\frac{y(0)+\dot{y}(0)}{2}$ and $C_{2}=\frac{y(0)-\dot{y}(0)}{2}$. 
This contradiction arose from the reduction of the common zero and the pole $s=1$, which is inadmissible in this case. This means that the same unstable zeros and poles cannot be reduced.

The inadmissibility of reducing the same unstable zeros and poles is also explained physically. If we have a system in which a link with an unstable pole precedes a link with an unstable zero, then when the input to this system any signal in the first link oscillations occur, and the second link will form these oscillations for the rest of the system. If a block that has a unstable zero precedes a unstable pole, then vibrations will also cause internal system noise. As for the same stable zeros and poles, the operation of reducing them does not lead to absurd conclusions. If we summarize this for real physical systems, then this generalization can be reduced to two positions:

1. In physical systems, it is not possible to completely compensate for the time constants due to measurement errors and subsequent technical implementation. Therefore, such compensation is always made with some previously unknown error.

2. Noise and interference (power line, FM-radio or mobile signaling etc.) in expressions for $C_{1}=$ $\frac{y(0)+\dot{y}(0)}{2}$ i $C_{2}=\frac{y(0)-\dot{y}(0)}{2}$ produce the value of the constants different, which makes it impossible to fully compensate for the components with different signs.

Now, given the fact that the problem of an unstable zero or pole is identified by its location on a complex plane, let us analyze the following variants:

- the pole in the left half plane causes a lag in the phase (from $0^{\circ}$ to $-90^{\circ}$ ) and decrease the gain at high frequencies;
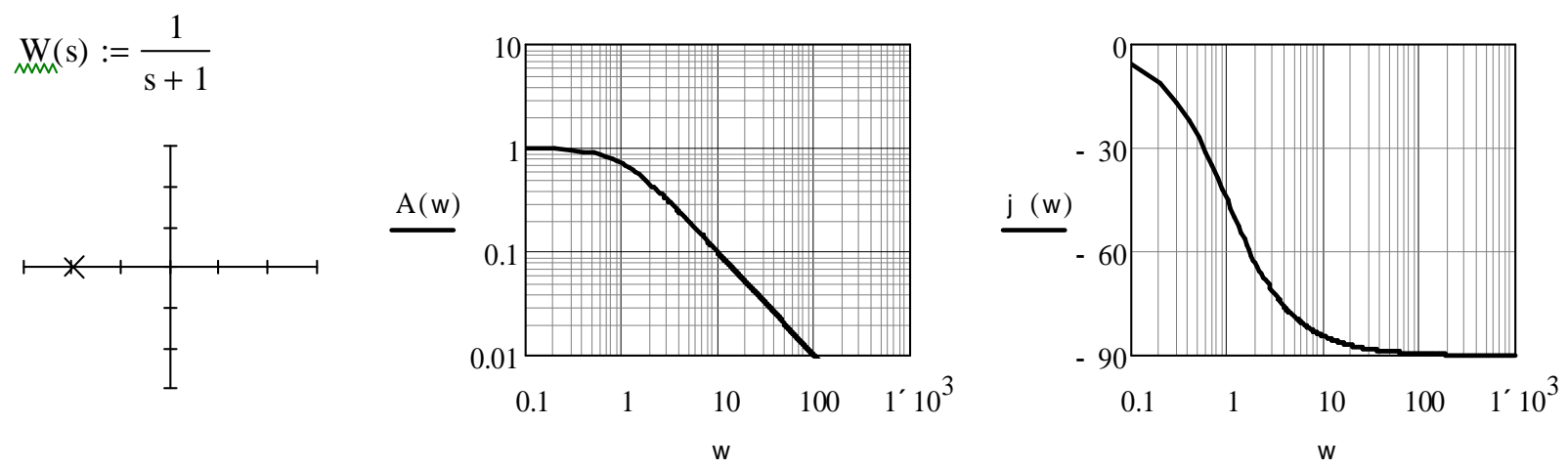

- zero in the left half plane leads to a phase advance (from $0^{\circ}$ to $90^{\circ}$ ) and increase the gain at high frequencies;
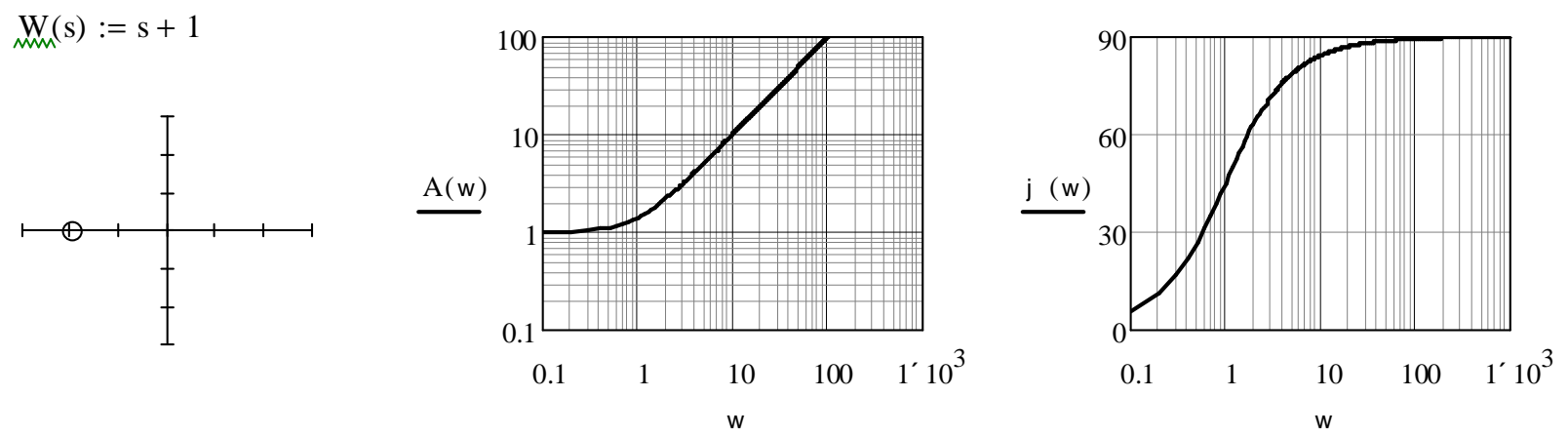

- the pole in the right half plane provides a virtual phase lead (from $-180^{\circ}$ to $-90^{\circ}$ ) and reducing the high-frequency gain; if a stable pole in the system corresponds to an unstable pole, then the phase delay will be zero. This is a very appreciated block, but because it is unstable, it can be suitable either in pulse systems or in coordinate trajectory systems by changing the position of the poles; 
$\mathrm{W}(\mathrm{s}):=\frac{1}{\mathrm{~s}-1}$
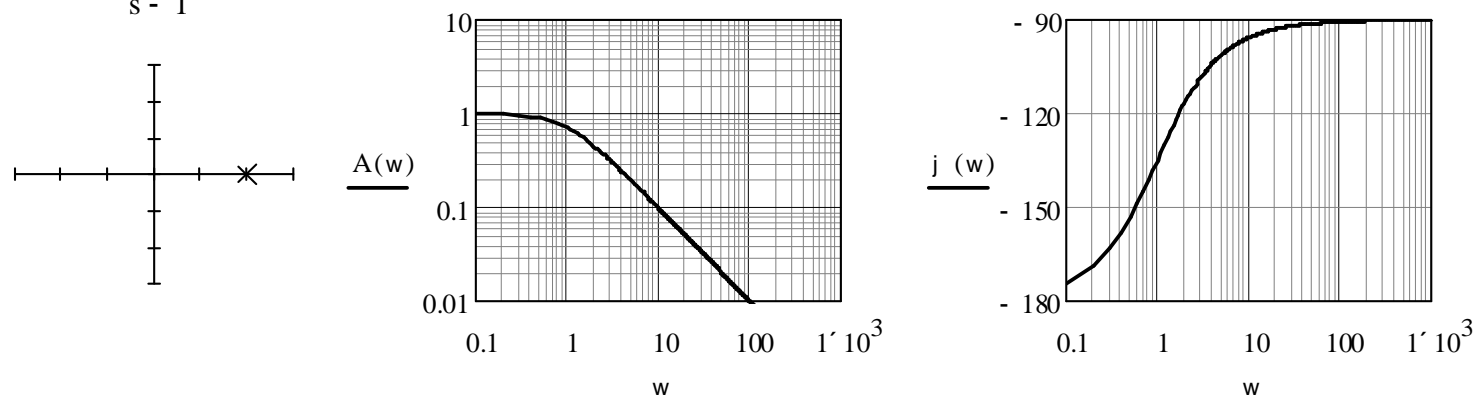

- Zero in the right half plane gives a virtual phase lag (from $180^{\circ}$ to $90^{\circ}$ ) and increase the gain at high frequencies. These two factors are undesirable, so the presence of such a block should be avoided wherever possible.
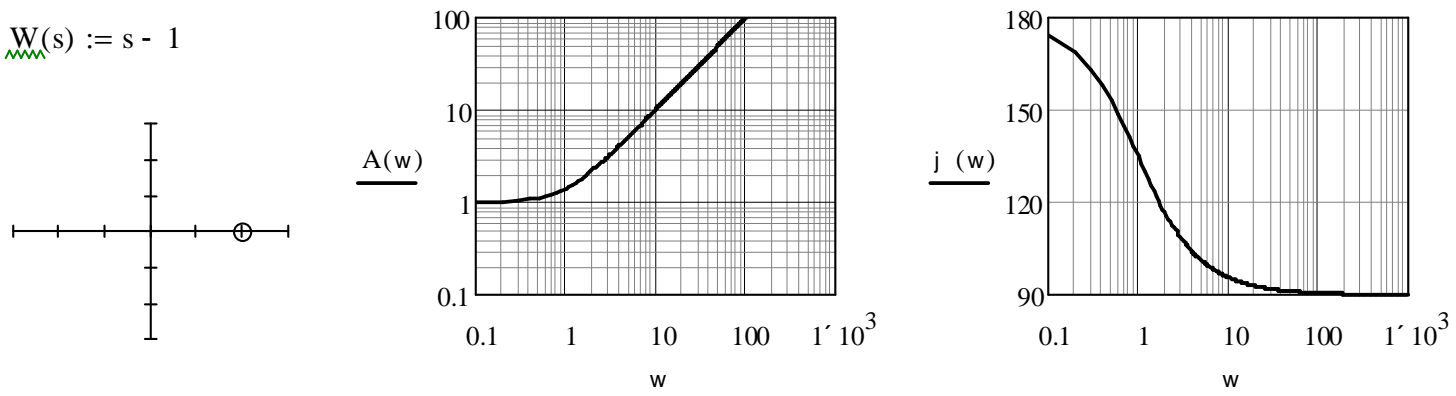

We illustrate the effects of the mentioned blocks with unstable poles and zeros on the appearance of logarithmic and phase frequency characteristics. Take for example the system described by the secondorder transfer function $W_{o}(s)=\frac{1}{(s+1)(0.1 s+1)}$ with corresponding amplitude and phase frequency characteristics (see below bode plots).
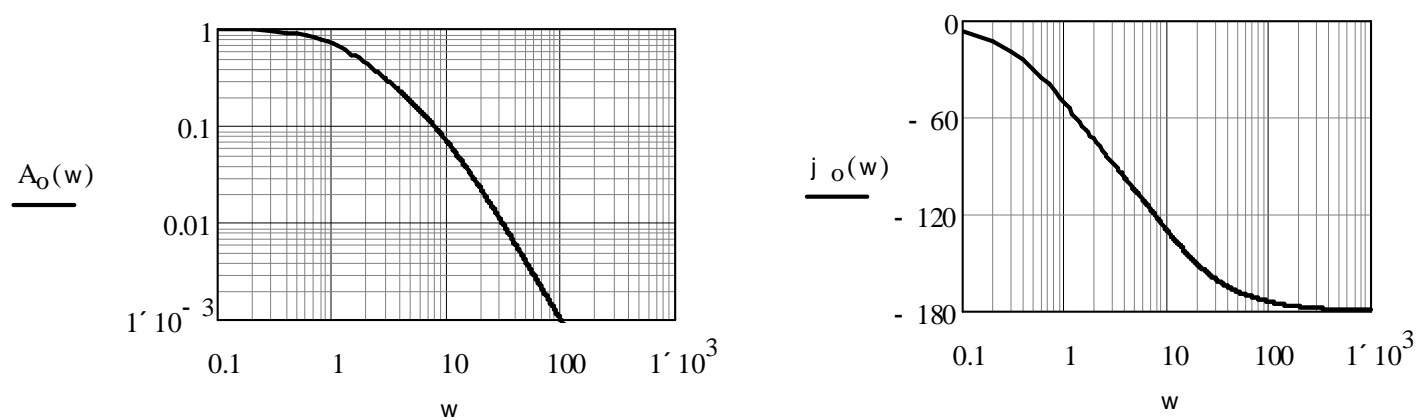

Accordingly, we obtain the resulting frequency characteristics (in form of bode plots):

- Pole in the left complex half plane.
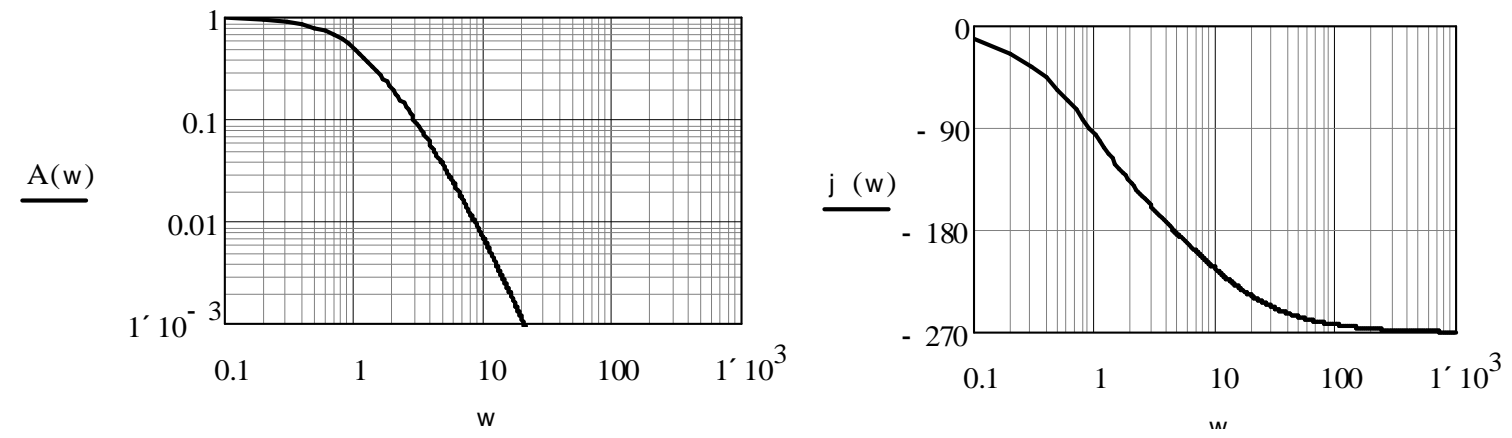
- Zero in the left complex half plane.
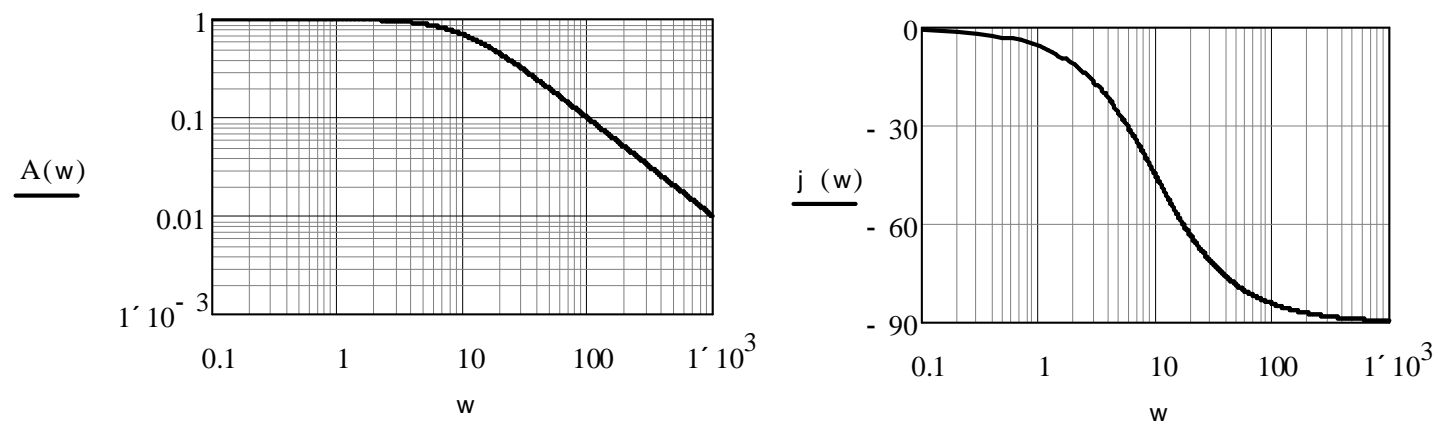

- Pole in the right half complex plane.
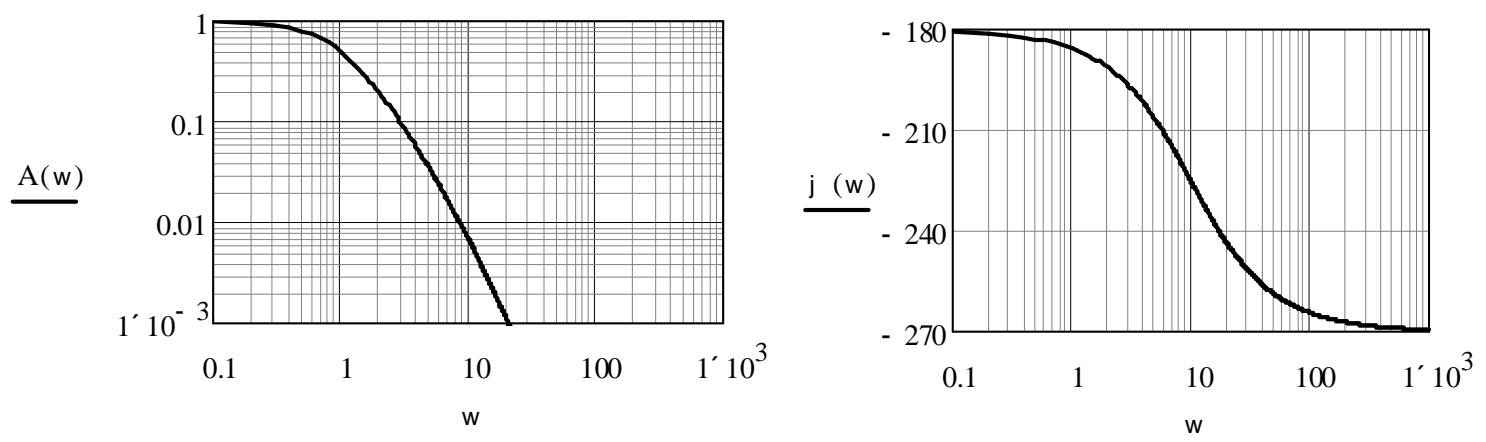

- Zero in the right half complex plane.
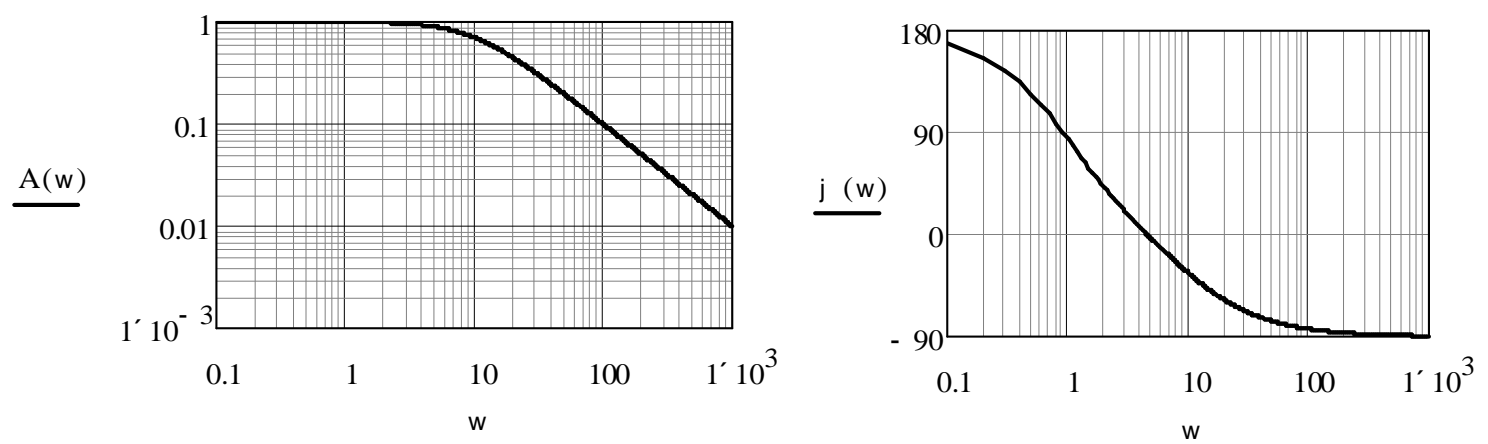

When analyzing the obtained phase frequency characteristics, it should be taken into account that the angle function used by mathematical programs works correctly only in the range from $-180^{\circ}$ to $+180^{\circ}$.

An analysis of the research results has shown that the use of apparently obvious mathematical transformations of transfer functions without taking into account the physical nature of the processes in the automatic control systems can lead to unexpected results, in particular, to the instability of a real closed system, although from the point of view of control theory compensation for unstable zeros / poles should occur. A comparative analysis of the above frequency characteristics makes it possible to confirm that the earlier declarations about the location of zeros and poles are correct.

\section{Conclusions}

Studies have shown that it is necessary to take into account the peculiarities of the mathematical apparatus of the automatic control theory, because it provides an idealized approach to the analysis and synthesis of automatic control systems. In the case of traditional transfer functions with zeros and poles, there are no problems in the left complex half-plane, since such objects are stable. In the case of unstable 
zeros and poles, different real results are possible, which are related to the nature of transients in blocks with unstable poles.

\section{Perspective for further research}

This article begins the direction of researches on the formation and analysis of characteristic equations coefficients of feedback dynamic systems with unstable zeros and poles of the open system in terms of preserving the required stability condition of $n$-order dynamic systems.

\section{References}

1. Otto J. M. Smith. Feedback Control Systems. - McGrow-Hill Book Company, Inc. New York, Toronto, London, 1958.

2. Transfer Functions, Poles and Zeros https://www.maplesoft.com/content/EngineeringFundamentals/10/MapleDocument_10/Transfer\%20Functions, \%20Poles\%20and\%20Zeros.pdf.

3. Understanding Poles and Zeros. [Massachusetts Institute of Technology Department of Mechanical Engineering]. Part 2.14 - Analysis and Design of Feedback Control Systems - http://web.mit.edu/2.14/www/Handouts/PoleZero.pdf.

4. John J. D’Azzo, Constantine H. Houpis, Stuart N. Sheldon. Linear Control System Analysis and Design with MATLAB. Fifth Edition, Revised and Expanded. Copyright (C) 2003 by Marcel Dekker, Inc. - New York, Basel [ISBN: 0-8247-4038-6].

5. W. Bolton. Control Systems. - Elsevier, 2002. [ISBN: 9780750654616].

6. Karl J. Aström, Richard M. Murray. Feedback Systems. An Introduction for Scientists and Engineers. Princeton University Press, 2009 [ISBN-10: 0-691-13576-2].

7. Shlomo Engelberg. A Mathematical Introduction to Control Theory. Copyright (C) 2005 Imperial College Press [ISBN 1-86094-570-8].

8. Richard C. Dorf, Robert H. Bishop. Modern Control Systems. Twelfth Edition. - Prentice Hall, Copyright (C) 2011 [ISBN-10:0-13-602458-0].

9. MATLAB: The Language of Technical Computing, User's Guide. The MathWorks, Inc., https://www.mathworks.com/help/index.html.

10. Control System Toolbox. Design and analyze control systems. The MathWorks, Inc. - https://www.mathworks.com/help/control/index.html.

Я. Ю. Марущак

Національний університет “Львівська політехніка”, кафедра електромехатроніки та комп’ютеризованих електромеханічних систем, yaroslav.y.marushchak@1pnu.ua

B. I. Мopo3

Національний університет “Львівська політехніка”, кафедра електромехатроніки та комп’ютеризованих електромеханічних систем volodymyr.i.moroz@lpnu.ua

В. Б. Цяпа

Національний університет “Львівська політехніка”, кафедра електромехатроніки та комп’ютеризованих електромеханічних систем volodymyr.b.tsiapa@1pnu.ua

І. Р. Головач

Національний університет “Львівська політехніка", кафедра електромехатроніки та комп’ютеризованих електромеханічних систем ihor.r.holovach@lpnu.ua 
Influence analysis of unstable zeroes and poles on the stability of the Feedback Systems

І. В. Чупило

Національний університет “Львівська політехніка", кафедра електромехатроніки та комп’ютеризованих електромеханічних систем iqorchupylo@ukr.net

\section{АНАЛІЗ ВПЛИВУ НЕСТІЙКИХ НУЛІВ І ПОЛЮСІВ НА СТІЙКІСТЬ ЗАМКНУТИХ СИСТЕМ, ПОВЕДІНКА ЯКИХ АПРОКСИМУЄТЬСЯ ПЕРЕДАВАЛЬНИМИ ФУНКЦІЯМИ ДРУГОГО ПОРЯДКУ}

() Марущзак Я. Ю., Мороз В. І., Цяпа В. Б., Головач І. Р., Чупило І. В., 2020

3 огляду на теорію автоматичного керування, не повинно бути різниці в поведінці між об'єктом, який задано набором передатних функцій, що відповідно поєднані між собою, так і реальним об'єктом, що відповідає такій теоретичній структурі зі заданими передавальними функціями. Відповідно до цього, проведено узагальнений аналіз гіпотези Отто Сміта стосовно показників стійкості в системах автоматичного керування 3 нестійкими нулями та полюсами передавальних функцій другого порядку. У зв'язку з тим, що поведінка більшості технічних об'сктів може бути описана передавальною функцією другого порядку, основний акцент зроблено саме на передатній функції зі знаменником (характеристичним рівнянням) другого порядку з нестійкими нулями і полюсами. У статті для опису використано як апарат передавальних функцій, так і структурні моделі відповідного рівня, що дало змогу зробити їхній опис наочним. Виконано узагальнений опис системи автоматичного керування другого порядку 3 від'смним жорстким зворотним зв'язком. Для такої системи сформовано теоретичні критерії стійкості стосовно її параметрів на підставі необхідних і достатніх умов стійкості.

На підставі узагальненого опису передавальною функцією другого порядку виконано дослідження систем автоматичного керування 3 різними варіантами розміщення на комплексній площині нестійких нулів і полюсів передавальної функції розімкнутої системи. Виклад матеріалу супроводжусться численними прикладами, для яких розглянуто випадки передавальних функцій як 3 дійсними полюсами, так і 3 парою комплексно-спряжених полюсів. Для кожного наведеного в статті прикладу розглянуто випадок як розімкнутої системи, так і замкнутої системи $з$ одиничним зворотним зв'язком. Обидва випадки для кожного прикладу проілюстровано графіками логарифмічних амплітудно-частотних i фазо-частотних характеристик i перехідною функцісю.

Проведені дослідження в статті проілюстровано графіками логарифмічних амплітудночастотних і фазо-частотних характеристик і перехідних функцій, які для кожного прикладу отримані з використанням математичних застосунків MATLAB (разом з бібліотекою Control System Toolbox) i Mathcad. За результатами проведених досліджень підтверджено висновки О. Сміта про відмінність у поведінці реальних фізичних систем з нестійкими нулями і полюсами та теоетично отриманими моделями з аналогічними передавальними функціями.

Ключові слова: нулі та полюси передавальних функцій, передавальні функції, системи автоматичного регулювання. 